\title{
Morphology Analysis of Fine Particles in Background Station of
}

\author{
Malaysia \\ Teh Nur Amalina Mohd Zaki ${ }^{1}$, Noor Faizah Fitri Md Yusof ${ }^{1 *} \&$ Syabiha Shith ${ }^{1}$ \\ ${ }^{1}$ School of Civil Engineering, Universiti Sains Malaysia, Nibong Tebal, Pulau Pinang, Malaysia \\ *Noor Faizah Fitri Md Yusof, E-mail: noorfaizah@usm.my
}

\begin{abstract}
A study have been conducted at Jerantut, Pahang. PM 2.5 concentrations were collected continously for 14 days and were analyzed to investigate time series and diurnal variations. Range of $P M_{2.5}$ concentration was between $6.0 \mu \mathrm{g} / \mathrm{m}^{3}$ and $98 \mu \mathrm{g} / \mathrm{m}^{3}$ with average $30.43 \pm 15.07 \mu \mathrm{g} / \mathrm{m}^{3}$. The mean temperature was $28.61^{\circ} \mathrm{C}$, while relative humidity and wind speed were $76.49 \%$ and $0.56 \mathrm{~m} / \mathrm{s}$. From hourly variations, the percentage of $P M_{2.5}$ concentration that exceed USEPA and WHO standards are $30.36 \%$ and $56.85 \%$, respectively. Due to rush hour, diurnal pattern shows that PM..5 concentration had the first peak between 6.00 to $9.00 \mathrm{~h}$, the second peak between 12.00 to $13.00 \mathrm{~h}$ and the third peak between 19.00 to 21.00 h. PM..5 shows a weak negative linear relationship with wind speed and temperature but shows a weak positive linear relationship with relative humidity. Morphology characteristic provides information about particle sources, atmospheric history, formation, reactivity, transport and removal of atmospheric chemical species. From FESEM analysis, the particles were categorized into two groups that are biological particles and anthropogenic particles. The biological particles such as fungal spore, brochosome and fungal hyphae were recognised from their morphology characteristics while anthropogenic particles such as soot were recognised from their morphology characteristics and weight percentage of elemental components.
\end{abstract}

\section{Keywords}

$P M_{2.5}$ concentration, meteorological parameters, biological particles, anthropogenic particles

\section{Introduction}

According to WHO (2006), the evidence on atmospheric Particulate Matter (PM) and its public health impact is consistent in showing adverse health effects at exposures that are currently experienced by in both developed and developing countries. Atmospheric Particulate Matter (PM) is a combination of solid and aqueous species which enter the atmosphere by anthropogenic and natural pathways. It can be divided into fine, which size is less then $2.5 \mu \mathrm{m}$, and coarse particles, which size is more than $2.5 \mu \mathrm{m}$ up to $10 \mu \mathrm{m}$. Fine particulate matter or $\mathrm{PM}_{2.5}$ which primarily emitted directly from combustion processes has most concern towards the health effect due to its toxicological and physiological considerations which suggest that $\mathrm{PM}_{2.5}$ may give the largest affect in human health (Pope III \& 
Dockery, 2006). Eventhough the toxicological is important in health concern, but it does not determine the noxiousness of the particles and their morphology characteristics (i.e., shape and surface properties) affect their dynamic behaviour and thermodynamic properties, which will impact on their biological activity (Broday \& Rosenzweig, 2011). Therefore, the particles morphological properties show how the particles stick and agglomerate that affect the way they interact with other bodies (Shi et al., 2015). A background station can provide very useful air quality information on a regional scale (USEPA, 2013). Jerantut, Pahang was established by Department of Environment (DOE), Malaysia as a rural background station for comparison of observations from other rural, urban and suburban monitoring stations. However, there is no studies focusing on concentration and morphological characteristics of $\mathrm{PM}_{2.5}$ from the station. Therefore, this research aims to analyze the level $\mathrm{PM}_{2.5}$ concentration and meteorological parameters, and to investigate the morphological and elemental characterization of $\mathrm{PM}_{2.5}$ in the middle of Peninsula Malaysia.

\section{Methodology}

\subsection{Location of Sampling Station}

The air quality data used for this research was obtained from Batu Embun Meteorological Station, Jerantut, Pahang. This location has been established as a background air monitoring station by the Department of Environment (DOE), Malaysia. Batu Embun station is located in the middle of the Peninsula Malaysia with coordinates N03 ${ }^{\circ}$ 58'15.29”, E102 ${ }^{\circ} 20^{\prime} 52.71$ ” (Figure 1) and is surrounded by natural forest and agricultural areas, as well as traditional Malaysian villages. The nearest town is Jerantut, which is about $8 \mathrm{~km}$ from the station. A few short-term studies have stated that the air quality level at this monitoring station is influenced by local open burning, soil dust and a low number of motor vehicles (Azmi et al., 2010; Banan, 2013). This may be due to the presence of a two-lane paved road close to the monitoring site $(<1 \mathrm{~km})$ and villages, as well as modern housing areas within $10 \mathrm{~km}$ radius from the station (Latif et al., 2014). Besides that, from Figure 1, in south area of the station, there were several possible sources that may contribute to $\mathrm{PM}_{2.5}$ (i.e., construction sites, industries and residential areas). 


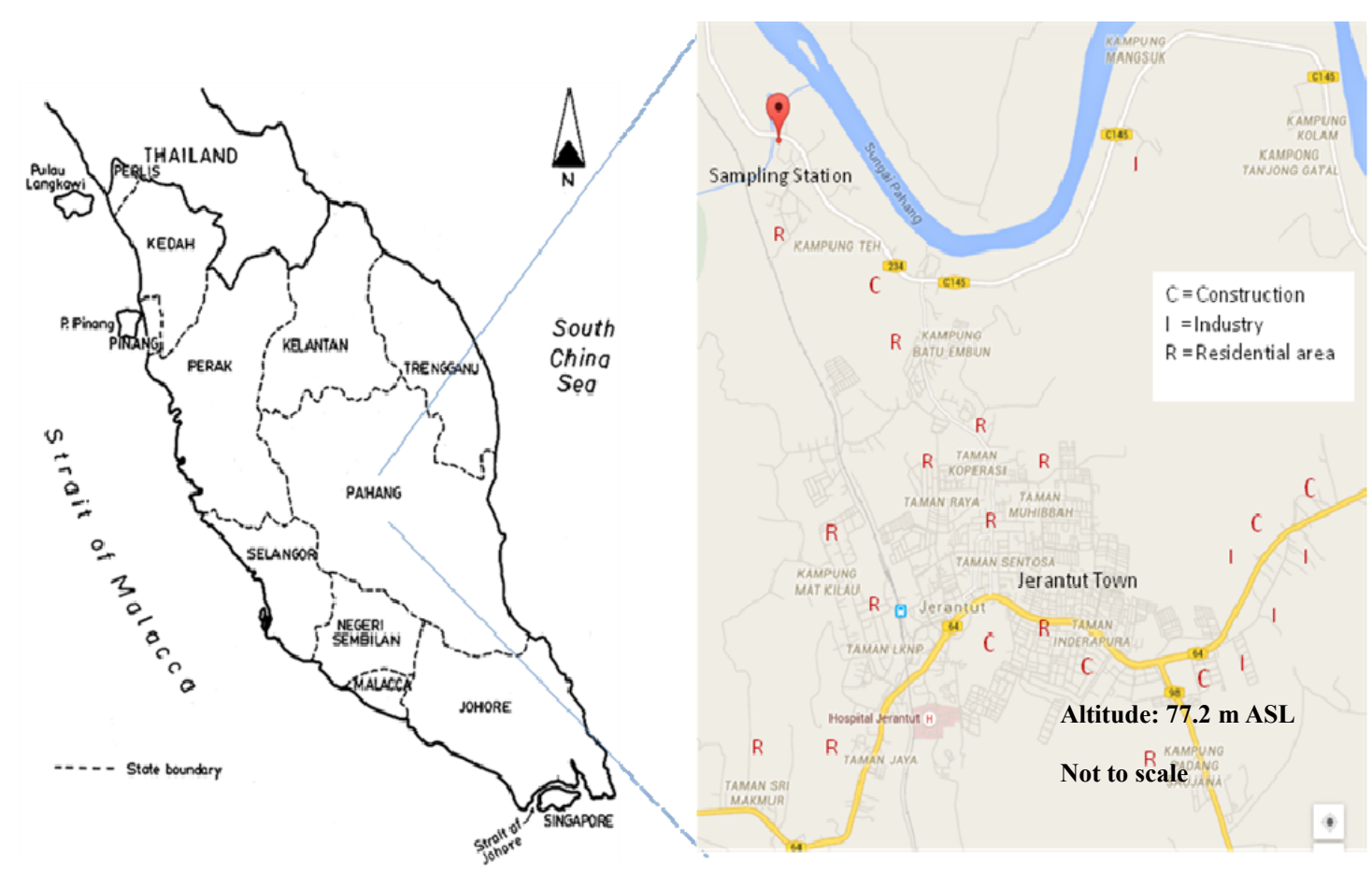

Figure 1. Location of the Monitoring and Sampling Station

\subsection{Ambient Sampling}

Hourly $\mathrm{PM}_{2.5}$ concentration and meteorological parameters such as wind speed, wind direction, ambient temperature and relative humidty were measured for 14 days from 11th June 2015 to 24th June 2015. The data measuring was performed using portable Beta Attenuation Monitor (E-BAM) (Met One Instrument Inc., Oregon) continuously for 24 hours.

The glass-fiber filter tape (\#460130; Met One Instruments Inc., Grants Pass, Oregon, USA) used in the E-BAM was composed of aluminosilicates and contains other elements and compounds that might disturb the chemical analysis (Watson et al., 2012). Particle deposits from a sample flow rate of $16.7 \mathrm{~L}$ $\min ^{-1}$ were focused on a $11 \mathrm{~mm}$ diameter spot. Then, the tape moved when the E-BAM detected a pressure drop due to excessive particle loading. The filter tape with sample spots were unrolled and the spots were cut and kept under $4^{\circ} \mathrm{C}$. Several samples were choosen based on high concentration recorded at specific hour.

\subsection{Laboratory Analysis}

Sample spots were punched using a $12 \mathrm{~mm}$ diameter steel punch. The whole sample spot was mounted on a stub with conductive carbon tape, then coated with a thin layer of platinum by Precision Etching Coating System (PECS) Model 682 (Gatan Inc., USA). The coated sample spots were examined manually in Extreme High Resolution Field Emission Scanning Electron Microscope (XHR-FESEM) Model FEI Verios 460L, coupled with Energy Dispersive X-ray Spectrometer (Oxford Silicon Drift Detector-X-Max EDS/EDX Detector) at magnifications ranging from 500x-35,000x to obtain the morphology, size, shape and elemental components of individual particles. 


\subsection{Pearson Correlation Analysis}

Correlation analysis is normally used with regression analysis because correlation analysis is used to measure the strength of association between two variables. The Pearson Correlation $(r)$ is used to find a correlation between at least two continous variables. The Pearson value is denoted as $r$. The $r$ value can fall between -1 and +1 (Dominick et al., 2012). Positive correlation indicates that both variables increse or decrease together. For negative correlation, one of the variable is either increase or decrease. If $r=0$, it shows that there is no linear relationship between two variables.

\section{Results and Discussions}

\section{1 $P_{2.5}$ Characterization}

$\mathrm{PM}_{2.5}$ concentration were compared with international standards, which are United State Environmental Protection Agency (USEPA) and World Health Organization (WHO) standards because $\mathrm{PM}_{2.5}$ concentration is not widely monitored in Malaysia. The lowest concentration level recorded was $6.00 \mu \mathrm{g} / \mathrm{m}^{3}$, while the highest concentration level recorded was $98.00 \mu \mathrm{g} / \mathrm{m}^{3}$. For all 14 days of monitoring, the average $\mathrm{PM}_{2.5}$ concentration does not exceeded USEPA standard for $\mathrm{PM}_{2.5}-24$ hours mean concentration, which is $35 \mu \mathrm{g} / \mathrm{m}^{3}$ but does exceeded WHO standard for $\mathrm{PM}_{2.5}-24$ hours mean concentration, which is $25 \mu \mathrm{g} / \mathrm{m}^{3}$. The mean temperature was $28.65^{\circ} \mathrm{C}$, while relative humidity and wind speed were $76.49 \%$ and $0.56 \mathrm{~m} / \mathrm{s}$ respectively (Table 1 ).

Table 1. Statistical Analysis of $\mathrm{PM}_{2.5}$ Concentration and Meteorological Parameters

\begin{tabular}{|c|c|c|c|c|c|c|}
\hline Parameter & $\begin{array}{l}\mathbf{P M}_{2.5} \text { Concentration } \\
\left(\mu \mathrm{g} / \mathrm{m}^{3}\right)\end{array}$ & Temperature $\left({ }^{\circ} \mathrm{C}\right)$ & $\begin{array}{l}\text { Relative } \\
(\%)\end{array}$ & Humidity & $\begin{array}{l}\text { Wind } \\
(\mathrm{m} / \mathrm{s})\end{array}$ & Speed \\
\hline Mean & 30.43 & 28.61 & 76.49 & & 0.56 & \\
\hline Standard & 15.07 & 3.86 & 15.38 & & 0.36 & \\
\hline Median & 29 & 27 & 85 & & 0.3 & \\
\hline Mode & 22 & 25 & 91 & & 0.3 & \\
\hline Minimum & 6 & 23 & 38 & & 0.3 & \\
\hline Maximum & 98 & 37 & 92 & & 1.8 & \\
\hline Variance & 227.20 & & & & & \\
\hline Skewness & 1.195 & & & & & \\
\hline Kurtosis & 2.217 & & & & & \\
\hline $25 \%$ & 20.00 & & & & & \\
\hline $50 \%$ & 29.00 & & & & & \\
\hline $75 \%$ & 38.00 & & & & & \\
\hline $98 \%$ & 72.86 & & & & & \\
\hline $99 \%$ & 84.89 & & & & & \\
\hline
\end{tabular}




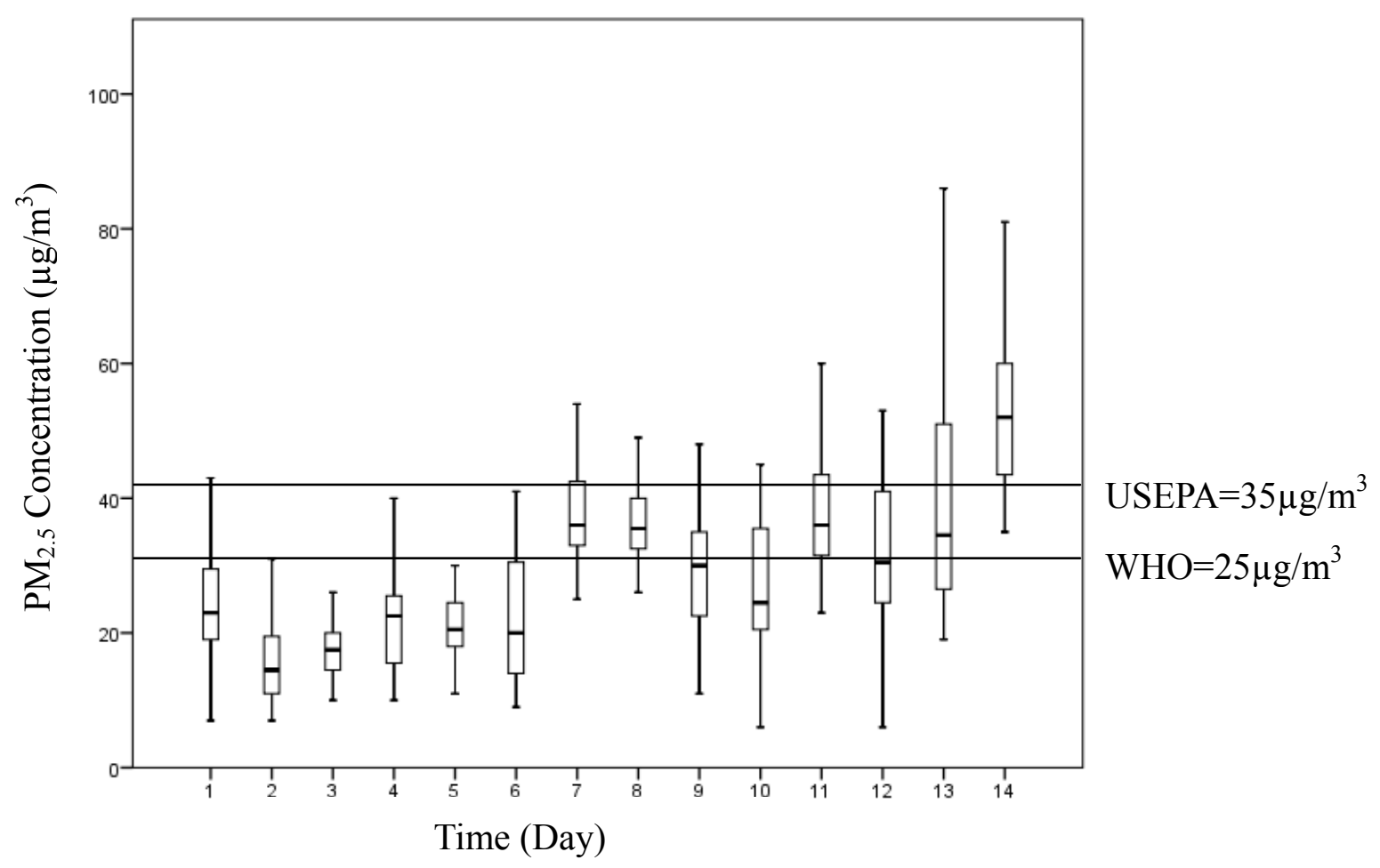

Figure 2. Boxplot of $\mathbf{P M}_{2.5}$ Concentration for 14 days

Boxplot of $\mathrm{PM}_{2.5}$ concentration for 14 days (24 hours) using E-BAM was plotted (Figure 2). The reference line of USEPA and WHO standard for 24 hours were drawn to show the exceedences that occured during the monitoring. The percentage of $\mathrm{PM}_{2.5}$ concentration that exceeds USEPA and WHO standards are $30.36 \%$ and $56.85 \%$, respectively. The highest $\mathrm{PM}_{2.5}$ concentration recorded was on 24 th June $2015(11.00 \mathrm{~h})$ with the recorded concentration is $98 \mu \mathrm{g} / \mathrm{m}^{3}$. 


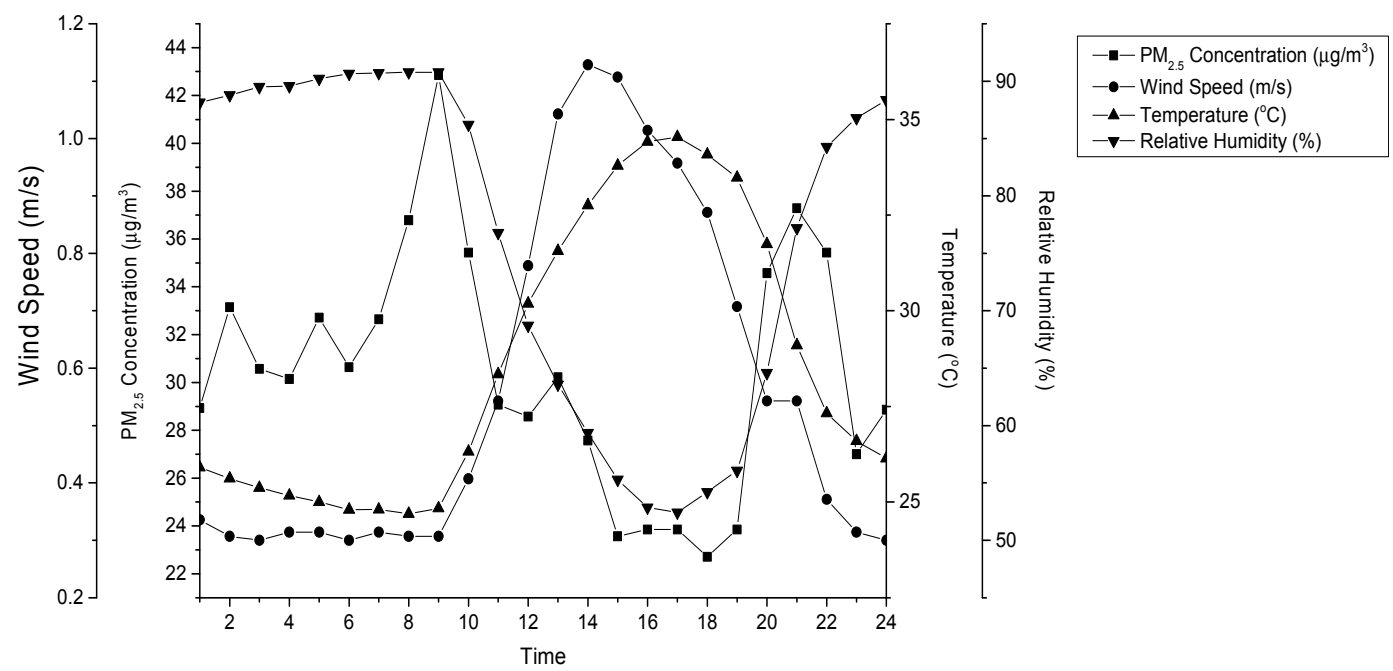

Figure 3. Diurnal Patterns of Hourly Average $\mathbf{P M}_{2.5}$ Concentration and Meteorological

Parameters

Diurnal patterns of $\mathrm{PM}_{2.5}$ concentration along with meteorological parameters are presented in Figure 3. The first peak of $\mathrm{PM}_{2.5}$ concentration occurs between 6.00 and $9.00 \mathrm{~h}$, the second peak occurs between 12.00 and $13.00 \mathrm{~h}$ and the third peak occurs between 19.00 and 21.00 h. At around 14.00-16.00 h, wind speed and temperature reached their highest levels with $1.13 \mathrm{~m} / \mathrm{s}$ and $34.54^{\circ} \mathrm{C}$ respectively. Conversely, $\mathrm{PM}_{2.5}$ concentration and relative humidity recorded their lowest levels at $16.00-18.00 \mathrm{~h}\left(23 \mu \mathrm{g} / \mathrm{m}^{3}\right.$ and $52.43 \%)$ respectively.

Table 2. Correlations (r) between $\mathbf{P M}_{2.5}$ and Meteorological Parameters

\begin{tabular}{|c|c|c|c|c|c|c|}
\hline Parameters & $\begin{array}{l}\mathrm{PM}_{2.5} \\
\left(\mu \mathrm{g} / \mathrm{m}^{3}\right)\end{array}$ & $\begin{array}{l}\text { Wind } \\
(\mathrm{m} / \mathrm{s})\end{array}$ & speed & $\begin{array}{l}\text { Temperature } \\
\left({ }^{\circ} \mathrm{C}\right)\end{array}$ & $\begin{array}{l}\text { Relative } \\
\text { (\%) }\end{array}$ & humidity \\
\hline $\mathrm{PM}_{2.5}\left(\mu \mathrm{g} / \mathrm{m}^{3}\right)$ & 1 & & & & & \\
\hline Wind speed $(\mathrm{m} / \mathrm{s})$ & $-0.190 *$ & 1 & & & & \\
\hline Temperature $\left({ }^{\circ} \mathrm{C}\right)$ & -0.095 & 0.765 & & 1 & & \\
\hline $\begin{array}{l}\text { Relative humidity } \\
(\%)\end{array}$ & 0.197 & -0.802 & & -0.975 & 1 & \\
\hline
\end{tabular}

* Correlation is significant at the 0.01 level (2-tailed).

The relationship between $\mathrm{PM}_{2.5}$ and meteorological parameters (wind speed, ambient temperature and relative humidity) was studied by Pearson Correlation analysis. The correlations between $\mathrm{PM}_{2.5}$ and 
meteorological parameters are shown in Table 2. Meteorological parameters recorded at Jerantut were found to correlate with each other apart from the correlation between $\mathrm{PM}_{2.5}$ concentration and ambient temperature. The highest positive significant correlation was between wind speed and ambient temperature $(r=0.765)$. The lowest negative significant correlation was between relative humidity and ambient temperature $(r=-0.975)$.
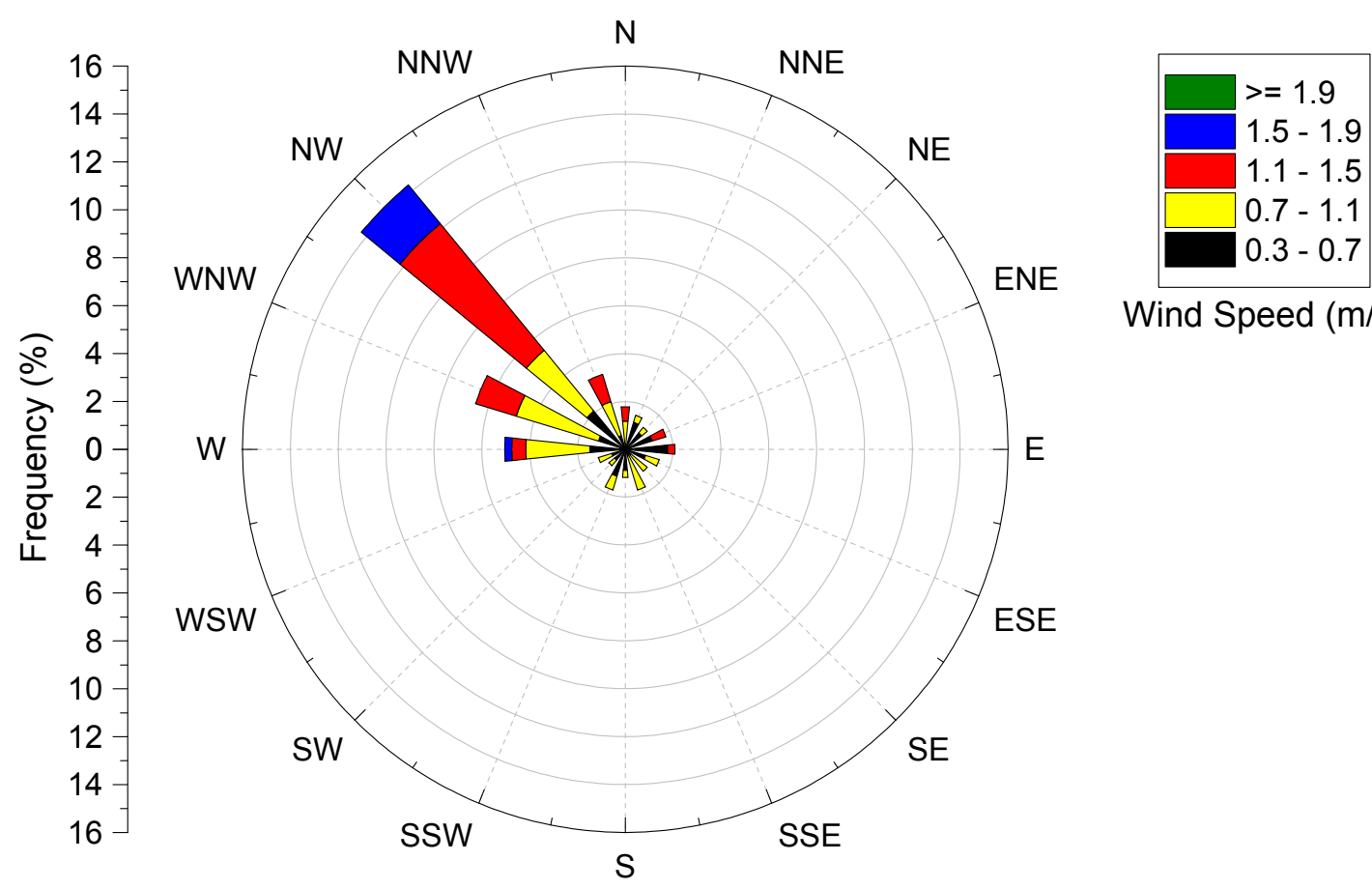

Wind Speed $(\mathrm{m} / \mathrm{s})$

Figure 4. Wind Rose Distribution for 14 Days

The wind variation patterns in this research, as shown by wind rose (Figure 4), were frequently coming from northwest direction. The highest concentration $\left(98 \mu \mathrm{g} / \mathrm{m}^{3}\right)$ was also coming from northwest direction $\left(290^{\circ}\right)$. Figure 5 shows part of biological particles seen by FESEM analysis. Particles in Figure 5(a) and (b) looks more likely as fungal spores. Figure 5(c) shows a collection of brochosomes (Coz et al., 2010). This type of particle were seen often during the analysis. Figure 5(d) appears to be a fungal hyphae (Martin et al., 2012). 

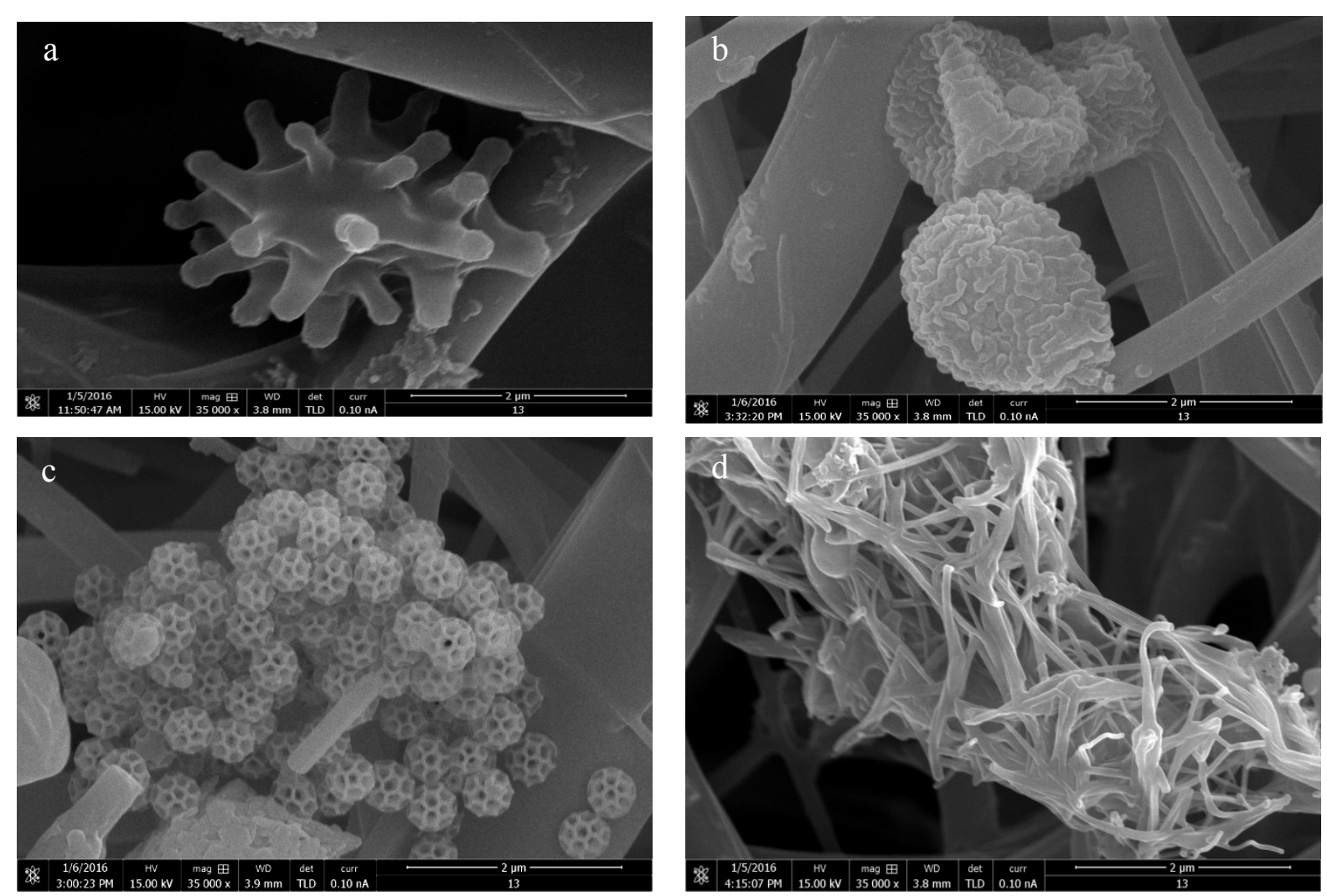

Figure 5. High Resolution FESEM Showing Biological Particles from Background Station

Figure 6(a) and (b) show the micrographs from high resolution FESEM of particle from anthropogenic sources and the elemental component of the particles. The elemental component of particles show that carbon, oxygen and silica rich particles dominate over other elements. Besides $\mathrm{C}, \mathrm{O}$ and $\mathrm{Si}$ rich particles, $\mathrm{F}, \mathrm{Na}, \mathrm{Al}, \mathrm{S}, \mathrm{K}, \mathrm{Ca}, \mathrm{Zn}$ and $\mathrm{Ba}$ rich particles are also present in this size range, which are $\mathrm{Si}>$ $\mathrm{C}>\mathrm{O}>\mathrm{Al}>\mathrm{Na}>\mathrm{K}>\mathrm{S}>\mathrm{Ba}>\mathrm{Zn}>\mathrm{Ca}>\mathrm{F}$ for Figure 6(a). For Figure 6(b), the trend of elements are $\mathrm{C}>\mathrm{Si}>\mathrm{O}>\mathrm{Al}>\mathrm{Na}>\mathrm{K}>\mathrm{S}>\mathrm{Ba}>\mathrm{Zn}>\mathrm{Ca}>\mathrm{F}$.
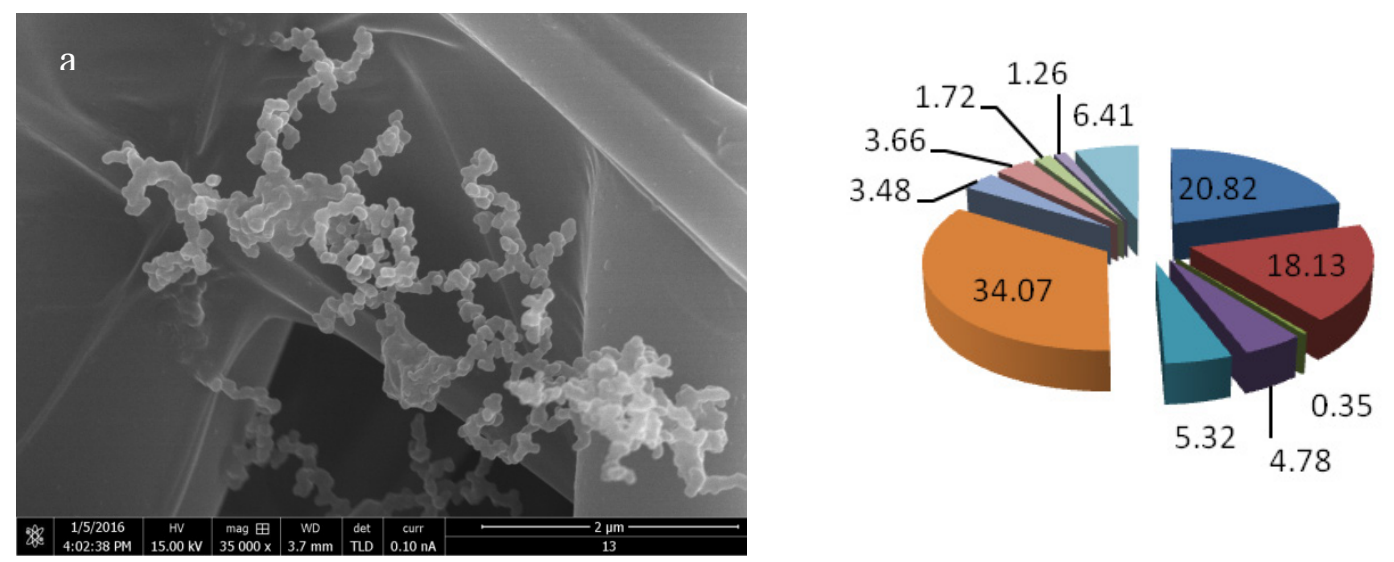

$\square \mathrm{C}$

$\square$

$\mathrm{F}$

$\square \mathrm{Ni}$

Al

- Si

$\square \mathrm{S}$

- $\mathrm{K}$

- $\mathrm{Ca}_{\mathrm{a}}$

$\mathrm{Zr}$

Ba 

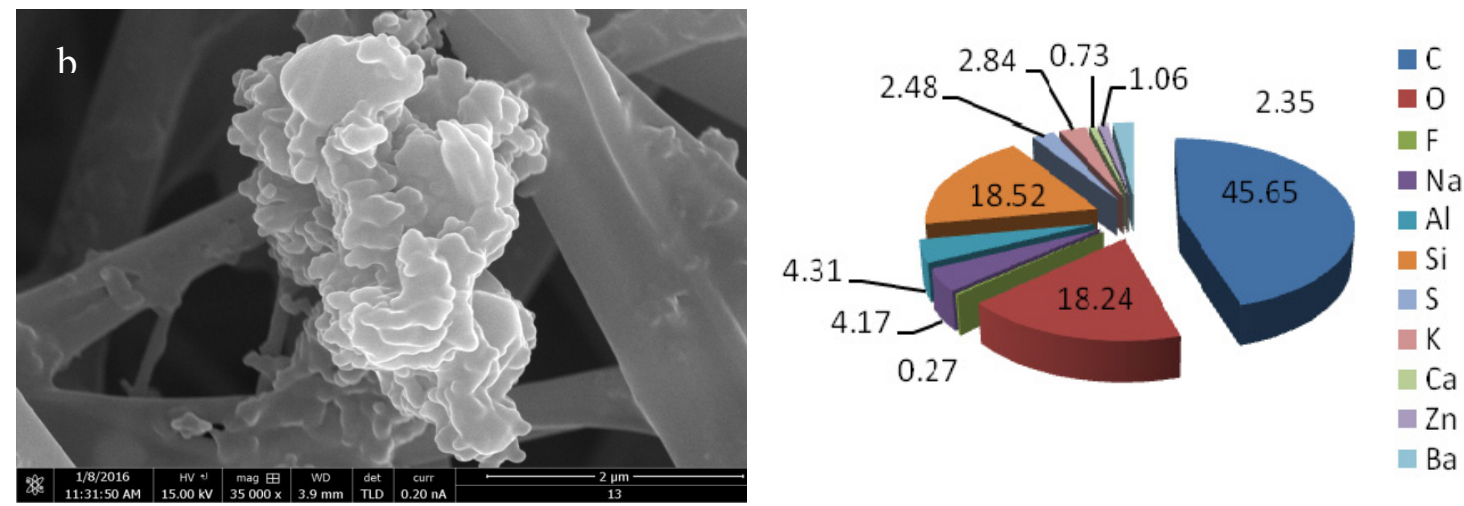

Figure 6(a) \& (b). High Resolution FESEM Micrographs with Weight Percentage of each Element of the Particle from Anthropogenic Sources

\section{Discussions}

This research shows the trend of $\mathrm{PM}_{2.5}$ concentration, morphological and elemental components of the particle at a background station in Malaysia. The data from monitoring were analyzed to investigate boxplot, diurnal patterns of relationship between $\mathrm{PM}_{2.5}$ and meteorological parameters. Range of $\mathrm{PM}_{2.5}$ concentration are from $6 \mu \mathrm{g} / \mathrm{m}^{3}$ to $98 \mu \mathrm{g} / \mathrm{m}^{3}$ with average concentration is $30.43 \pm 15.07 \mu \mathrm{g} / \mathrm{m}^{3}$. The mean temperature was $28.65^{\circ} \mathrm{C}$, while relative humidity and wind speed were $76.49 \%$ and $0.56 \mathrm{~m} / \mathrm{s}$ respectively. The concentrations of $\mathrm{PM}_{2.5}$ recorded at Jerantut station is to be expected a result of different weather conditions, increasing number of motor vehicles on the road, anthropogenic activities such as burning of fallen leaves as well as regional emissions, especially those resulting from industrial activity and agricultural burning. The first and third peaks can be largely attributed to rush hour traffic in the morning and evening. For the third peak, vehicles emission from school buses and parents vehicles that took students from school nearby may contributed to the increasing of $\mathrm{PM}_{2.5}$ concentration. $\mathrm{PM}_{2.5}$ concentration was negatively influenced by the wind speed and temperature. Background station showed strong relationship between relative humidity and temperature. This is because, as the value of relative humidity increase, the value of ambient temperature normally will be decreased due to the weather and location. The correlation between $\mathrm{PM}_{2.5}$ concentration and wind speed is significant. This is because when the wind speed is low, it can move the pollutants within a certain distance, but higher wind speed can transport large quantities of dust particles from a long distance (Wang \& Ogawa, 2015). The relative humidity showed positive correlation with $\mathrm{PM}_{2.5}$ concentration. When the humidity is high, the particle hygroscopic growth and condensation likely result in an increase of the coarse aerosol fraction, therefore, fewer particles were collected as part of the $\mathrm{PM}_{2.5}$ fraction (Martuzevicius et al., 2004).

Highest concentration was coming from northwest direction. Open burning and agriculture activities from villages nearby and biological particles from the forest may contribute to high $\mathrm{PM}_{2.5}$ concentration. Three different samples (June 15th, 18th \& 22nd) were analyzed using high resolution Field Emission Scanning Electron Microscopy (FESEM) coupled with Energy-Dispersive X-ray (EDX) 
analysis to identify their grain size, morphology and chemical elemental components of individual particles. The samples were selected according to their $\mathrm{PM}_{2.5}$ concentration and wind direction. The concentration selected were higher than USEPA standard which is $35 \mu \mathrm{g} / \mathrm{m}^{3}$ and the wind direction was blowing from southeast area. In southeast area, as shown in Figure 1, there were a lot of anthropogenic activities. With high concentration, variety of particles' morphology and elemental characteristic could be found. Even though the highest concentration was coming from northwest direction, but if the samples were chosen from that direction, morphological and elemental characteristics might not vary due to limited possible sources. Morphology and elemental characterization of individual atmospheric particles are very important due to their effect on radiative and chemical properties (Pipal \& Gursumeeran, 2015) and also provide useful information about their sources, atmospheric history, formation, reactivity, transport and removal of atmospheric chemical species (Lu et al., 2006; Adachi \& Buseck, 2010; Lee \& Hieu, 2013).

The biological particles such as fungal spore, brochosome and fungal hyphae were recognised from their morphology characteristics while anthropogenic particles such as soot were recognised from their morphology characteristics and weight percentage of elemental components. According to the morphology analysis, two main particle categories were observed, which are particle of biological sources include materials of organic origin such as pollen, bacteria, fungal spores, vegetative detritus and brochosomes (Huffman et al., 2012) and anthropogenic sources, mostly emitted from high temperature combustion processes were characterized by their spherical shapes and smooth surfaces (Tasić et al., 2006; Martin et al., 2010). From the analysis, most of the particles from sample collected appeared as biological particles, where the rest were anthropogenic particles. Biological particle can be living or dead and their size can span physical dimensions from a few nanometers to hundreds of micrometers. They can be recognized by their morphological characteristics (Tasić et al., 2006). Particle from anthropogenic sources occured as individual particles and also in an aggregate form. Percentage of elemental components of the particle are different according to the sources.

Biological particles are severe in reproduction processes of many organisms because they spread genetic material over long distances (Huffman et al., 2012). They can also negatively affect agricultural (Wittmaack et al., 2005) and public health as pathogenic agents, can be used as agents of biological warfare and can affect atmospheric systems by acting as nuclei on which cloud water droplets and ice particles may form (Cox \& Wathes, 1995; Pöschl, 2005; Jaenicke et al., 2007; Prenni et al., 2009; Després et al., 2012). Brochosomes were produced by leafhoppers as a very efficient water-repellent and anti-adhesive protective surface coating (Wittmaack, 2005). They are spherical honeycombs, where the size are 200-700 $\mathrm{nm}$ in diameter, with pentagonal and hexagonal wall compartments open into the hollow core (Rakitov \& Gorb, 2013). As background station was originally a rural area and the station was surrounded with trees, the particles from biological sources were the dominant particles that have been observed.

The trend of elemental components from Figure 6(a) and 6(b) indicate the presence of soot. Soot 
particles are characterized by agglomeration of fine spherical primary particles that varies from chains to simple clusters, with size 1-2 $\mu \mathrm{m}$ (Tasić et al., 2006; Yue et al., 2006) and scaly fine particle aggregates with a bitty appearance (Wu et al., 2015). It might come from vehicle emissions.

\section{Conclusions}

This research shows the trend of $\mathrm{PM}_{2.5}$ concentration and meteorological parameters, and characteristics of morphological and elemental components of the particles at background station in Malaysia from June $11^{\text {th }}$ to June $24^{\text {th }}$, 2016. Range of $\mathrm{PM}_{2.5}$ concentration was between $6 \mu \mathrm{g} / \mathrm{m}^{3}$ to $98 \mu \mathrm{g} / \mathrm{m}^{3}$ with concentration $30.43 \pm 15.07 \mu \mathrm{g} / \mathrm{m}^{3}$. The average temperature, relative humidity and wind speed were $28.65^{\circ} \mathrm{C}, 76.49 \%$ and $0.56 \mathrm{~m} / \mathrm{s}$, respectively. Average concentration of $\mathrm{PM}_{2.5}$ at background station of Malaysia did not exceed USEPA standard for $\mathrm{PM}_{2.5}-24$ hours mean concentration, but did exceed WHO standard for $\mathrm{PM}_{2.5}-24$ hours mean concentration. From hourly variations, the percentage of $\mathrm{PM}_{2.5}$ concentration that exceed USEPA and WHO standards are $30.36 \%$ and $56.85 \%$, respectively. Diurnal patterns shows that $\mathrm{PM}_{2.5}$ concentration increase in the morning and at the late evening due to rush hour. The average wind rose plotted and the highest $\mathrm{PM}_{2.5}$ concentration did not affected by the current monsoon which is southwest monsoon. $\mathrm{PM}_{2.5}$ shows a weak negative linear relationship with wind speed $(-0.190)$ and temperature $(-0.095)$ but shows a weak positive linear relationship with relative humidity (0.197). Morphology provides information about particle sources, atmospheric history, formation, reactivity, transport and removal of atmospheric chemical species. From FESEM, the particles were categorized by two group which biological particles and anthropogenic particles. The biological particles such as fungal spore, brochosome and fungal hyphae were recognised from their morphology characteristics while anthropogenic particles such as soot were recognised from their morphology characteristics and weight percentage of elemental components.

\section{Acknowledgement}

The study was suppoorted by Universiti Sains Malaysia, Research University Grant (RUI account number: 1001/PAWAM/814183). In addition, authors also would like to thank the Ministry of Education Malaysia for supporting tertiary education of the first author.

\section{References}

Adachi, K., \& Buseck, P. R. (2010). Hosted and free floating metal-Bearing atmospheric nanoparticles in Mexico City. Environ. Sci. Technol, 44, 2299-2304.

Azmi, S. Z., Latif, M. T., Ismail, A. S., Juneng, L., \& Jemain, A. A. (2010). Trend and status of air quality at three different monitoring stations in the Klang Valley, Malaysia. Air Quality, Atmosphere \& Health, 3(1), 53-64.

Banan, N. (2013). Characteristics of surface ozone concentrations at stations with different backgrounds in the Malaysian Peninsula. Aerosol and Air Quality Research, 1090-1106. 
Broday, D. M., \& Rosenzweig, R. (2011). Deposition of fractal-like soot aggregates in the human respiratory tract. Journal of Aerosol Science, 42(6), 372-386.

Cox, C. S., \& Wathes, C. M. (1995). Bioaerosols Handbook. Lewis Publishers, Boca Raton, FL.

Coz, E., Artíñano, B., Clark, L. M., Hernandez, M., Robinson, A. L., Casuccio, G. S., ... Pandis, S. N. (2010). Characterization of fine primary biogenic organic aerosol in an urban area in the northeastern United States. Atmospheric Environment, 44(32), 3952-3962.

Després, V. R., Huffman, J. A., Burrows, S. M., Hoose, C., Safa-tov, A. S., Buryak, G. A., ... Jaenicke, R. (2012). Primary biological aerosol particles in the atmosphere: A review. Tellus B, 64, 15598. http://dx.doi.org/10.3402/tellusb.v64i0.15598

Dominick, D., Latif, M. T., Juahir, H., Aris, A. Z., \& Zain, S. M. (2012). An assessment of influence of meteorological factors on PM 10 and NO 2 at selected stations in Malaysia. Sustainable Environment Research, 22(2), 305-315.

United States Environmental Protection Agency. (2013). Quality assure handbook for air pollution measurement systems, 2, 348.

Huffman, J. A., Sinha, B., Garland, R. M., Snee-Pollmann, A., Gunthe, S. S., Artaxo, P., ... Pöschl, U. (2012). Size distributions and temporal variations of biological aerosol particles in the Amazon rainforest characterized by microscopy and real-time UV-APS fluorescence techniques during AMAZE-08. Atmospheric Chemistry and Physics, 12(24), 11997-12019.

Jaenicke, R., Matthias-Maser, S., \& Gruber, S. (2007). Omnipresence of biological material in the atmosphere. Environ. Chem, 4, 217-220.

Latif, M. T., Dominick, D., Ahamad, F., Khan, M. F., Juneng, L., Hamzah, F. M., \& Nadzir, M. S. M. (2014). Long term assessment of air quality from a background station on the Malaysian Peninsula. Science of The Total Environment, 2, 336-348, 482-483.

Lee, B. K., \& Hieu, N. H. (2013). Seasonal ion characteristics of fine and coarse particles from an urban residential area in a typical industrial city. Atmos. Res, 122, 362-377.

Lu, S. L., Shao, L. Y., Wu, M. H., \& Jiao, Z. (2006). Mineralogical characterization of airborne individual particulates in Beijing. J. Environ. Sci, 18, 90-95.

Martuzevicius, D., Grinshpun, S. A., Reponen, T., Górny, R. L., Shukla, R., Lockey, J., ... LeMasters, G. (2004). Spatial and temporal variations of $\mathrm{PM}_{2.5}$ concentration and composition throughout an urban area with high freeway density-The Greater Cincinnati study. Atmospheric Environment, 38(8), 1091-1105.

Pipal, A. S., \& Gursumeeran, S. P. (2015). Study of carbonaceous species, morphology and sources of fine $\left(\mathrm{PM}_{2.5}\right)$ and coarse $\left(\mathrm{PM}_{10}\right)$ particles along with their climatic nature in India. Atmospheric Research, 154, 103-115.

Pope, C. A., \& Dockery, D. W. (2006). Health effects of fine particulate air pollution: Lines that connect. Journal of the Air \& Waste Management Association (1995), 56(12), 709-742.

Pöschl, U. (2005). Atmospheric aerosols: Composition, transformation, climate and health effects. 
Angew. Chem. Int. Edit, 44, 7520-7540.

Prenni, A. J., Petters, M. D., Kreidenweis, S. M., Heald, C. L., Martin, S. T., Artaxo, P., ... Pöschl, U. (2009). Relative roles of biogenic emissions and Saharan dust as ice nuclei in the Amazon basin. Nat. Geosci, 2, 402-405.

Rakitov, R., \& Gorb, S. N. (2013). Brochosomal coats turn leafhopper (Insecta, Hemiptera, Cicadellidae) integument to superhydrophobic state. Tunisie Medicale, 91(2).

Shi, Y., Ji, Y., Sun, H., Hui, F., Hu, J., Wu, Y., ... Lanza, M. (2015). Nanoscale characterization of PM 2.5 airborne pollutants reveals high adhesiveness and aggregation capability of soot particles. Scientific Reports, 5(4), 11232.

Tasić, M., Đurić-Stanojević, B., Rajšić, S., Mijić, Z., \& Novaković, V. (2006). Physico-chemical characterization of $\mathrm{PM}_{10}$ and $\mathrm{PM}_{2.5}$ in the Belgrade urban area. Acta Chim. Slov, 53, 401-405.

Wang, J., \& Ogawa, S. (2015). Effects of meteorological conditions on $\mathrm{PM}_{2.5}$ concentrations in Nagasaki, Japan. International journal of environmental research and public health, 12(8), 9089-101.

Wittmaack, K. (2005). Brochosomes produced by leafhoppers-A widely unknown, yet highly abundant species of bioaerosols in ambient air. Atmospheric Environment, 39(6), 1173-1180.

Wittmaack, K., Wehnes, H., Heinzmann, U., \& Agerer, R. (2005). An overview on bioaerosols viewed by scanning electron microscopy. Science of the Total Environment, 346(1-3), 244-255.

World Health Organization. (2006). WHO Air quality guidelines for particulate matter, ozone, nitrogen dioxide and sulfur dioxide: Global update 2005: Summary of risk assessment. Geneva: World Health Organization, 1-22. Retrieved April 21, 2016, from http://whqlibdoc.who.int/hq/2006/WHO_SDE_PHE_OEH_06.02_eng.pdf?ua=1

Wu, Z., Liu, F., \& Fan, W. (2015). Characteristics of $\mathrm{PM}^{10}$ and $\mathrm{PM}_{2.5}$ at Mount Wutai Buddhism Scenic Spot, Shanxi, China. Atmosphere, 6(8), 1195-1210.

Yue, W., Li, X., Liu, J., Li, Y., Yu, X., Deng, B., ... Yang, S. (2006). Characterization of PM $_{2.5}$ in the ambient air of Shanghai city by analyzing individual particles. Science of the Total Environment, $368(2-3), 916-925$. 